\title{
Editorial
}

\section{Soil Erosion: Dust Control and Sand Stabilization}

\author{
Itzhak Katra
}

Department of Geography and Environmental Development, Ben Gurion University, Beersheba 8410501, Israel; katra@bgu.ac.il

Received: 4 November 2020; Accepted: 9 November 2020; Published: 13 November 2020

\begin{abstract}
This Special Issue on soil erosion invites novel and original articles based on physical and chemical theories, field and laboratory experimental, soil analyses, and/or statistical and mathematical modeling that advance our knowledge on dust control and sand stabilization.
\end{abstract}

Keywords: aeolian processes; arid areas; dust emission; dust sources; environmental pollution; infrastructures; human activities; particle size distribution; polymers; sand dune; sand transport; soil erosion; soil quality

\section{Soil Erosion by Wind}

Soil erosion by wind is significant to Earth systems and human health, e.g., [1-3]. Soil-derived dust particles with origins in various source areas constitute one of the major components of global aerosols. Annual global dust emissions from soils into the atmosphere are estimated to be as high as 3000 million tons, including particulate matter (PM) that is less than 10 micrometers in diameter (PM10) [4]. Climate change of drier conditions is associated with desertification and, thus, increased dust emission from soils and sand-dune transport. Moreover, many soils throughout the world are subjected to the impacts of rapid population growth and extensive land uses, including agricultural fields, grazing areas, unpaved roads, mines and quarries, waste soils, active sand dunes and sand sheets, and more. There is a strong interest in understanding the factors and processes of soil erosion by wind as well as in developing and applying methods to control dust emission from soils and to stabilize active sands. This Special Issue on soil erosion invites novel and original articles based on physical and chemical theories, field and laboratory experimental, soil analyses, and/or statistical and mathematical modeling that advance our knowledge on dust control and sand stabilization.

\section{Diverse Impacts and Solutions in Soil Erosion}

This Special Issue was introduced to collect the latest research on relevant topics to address present challenging issues in dust control and sand mobilization. The Special Issue contains information on applications of natural and synthetic materials to reduce soil erosion; development of materials and methods; experimental methods and modeling; impacts on the soil quality and the environments; quantification of the efficiency in dust control and sand stabilization applications. Eight papers were accepted for publication; six research papers, one review paper, and one technical note. The review paper of Lal [5] provides us with a complete picture of soil erosion and gaseous emissions. The large magnitude of annual erosion of soil organic carbon has severe adverse impacts on soil quality and functionality, and emission of multiple greenhouse gases (GHGs) into the atmosphere. Three papers focus on sand dunes. The paper of Bird et al. [6] was aimed to investigate the temporal trends of four taxonomic groups to determine the effect of vegetation removal on dune assemblages over a 12-year period. They show that fixed dune treatment had very little effect, while a stronger response was found in semi-fixed treatments in particular for mobile dune indicator species. The paper of Yang et al. [7] is about the characteristics of the aeolian dune, wind regime and sand transport in 
the Hobq Desert, China. Their work provides a scientific basis for the prevention and treatment of regional sand disasters. The paper of Wang et al. [8] on wind tunnel measurements of surface shear stress on an isolated dune downwind a bridge highlights the possible impacts on sand dune transport due to civil infrastructures. The other papers in this Special Issue focus on arid and semi-arid soils. The paper of Cheng et al. [9] is about the shearing behavior of the loess and post-harvest waste (PHW) mixture using small-scale and large-scale direct shear tests. Their work provides us with information on the ability of the loess-PHW mixture to resist seepage force and thus soil erosion on slopes. In the paper of Raveh-Amit and Tsesarsky [10], the biostimulation in desert soils for microbial-induced calcite precipitation (MICP) is a soil amelioration technique to prevent desertification and soil erosion. The results of their work demonstrate that biostimulated MICP is feasible in low-carbon mineral topsoils. The paper of Katra [11] was aimed to fill a clear gap in the efficiency of common product applications for reducing dust emission in quarry roads. The results of the wind tunnel experiments indicate that Hydrous magnesium chloride (Brine) was the most efficient compared with synthetic and organic polymers. The paper of Hanegbi and Katra [12] is a technical note on the development of a clay-based geopolymer for dust control and soil stabilization in semi-arid loess.

\section{Future Advances in Dust Control and Sand Stabilization}

Dust emission and sand mobilization can be reduced by using various applications. Products for dust control are based mainly on synthetic or natural polymers, which are applied by wetting the soil surfaces. A wide range of the products has been tested for dust emission by human activity such as mining and vehicles traveling on unpaved roads. Yet, there is a lack of fundamental research examining the efficiency of diverse products in the suppression of dust emission by wind. Moreover, further study is needed to investigate the possible environmental impacts of the diverse dust suppression substances, including the toxicity of atmospheric particulate matter when dust is emitted from the treated soils and/or soil-groundwater pollution because of vertical fluxes of the applied solutions on the surfaces. We aim to report on the future advances in the Special Issue "Soil Erosion: Dust Control and Sand Stabilization", Volume 2.

Funding: This research received no external funding.

Acknowledgments: This Special Issue is a result of a long-term work by all the authors, the reviewers, and the editorial team. A special thanks to Karena Pan, Section Managing Editor, Applied Sciences, MDPI.

Conflicts of Interest: The author declares no conflict of interest.

\section{References}

1. Katra, I.; Gross, A.; Swet, N.; Tanner, S.; Krasnov, H.; Angert, A. Substantial dust loss of bioavailable phosphorus from agricultural soils. Sci. Rep. 2016, 6, 24736. [CrossRef] [PubMed]

2. Kok, J.F.; Ridley, D.A.; Zhou, Q.; Miller, R.L.; Zhao, C.; Heald, C.L.; Ward, D.S.; Albani, S.; Haustein, K. Smaller desert dust cooling effect estimated from analysis of dust size and abundance. Nat. Geosci. 2017. [CrossRef] [PubMed]

3. Yitshak-Sade, M.; Novack, V.; Katra, I.; Gorodischer, R.; Tal, A.; Novack, L. Non-anthropogenic dust exposure and asthma medications purchase in children. Eur. Respir. J. 2015, 45, 652-660. [CrossRef] [PubMed]

4. Ginoux, P.; Prospero, J.M.; Gill, T.E.; Hsu, N.C.; Zhao, M. Global-scale attribution of anthropogenic and natural dust sources and their emission rates based on MODIS Deep Blue aerosol products. Rev. Geophys. 2012, 50, RG3005. [CrossRef]

5. Lal, R. Soil Erosion and Gaseous Emissions. Appl. Sci. 2020, 10, 2784. [CrossRef]

6. Bird, T.L.F.; Bouskila, A.; Groner, E.; Bar Kutiel, P. Can Vegetation Removal Successfully Restore Coastal Dune Biodiversity? Appl. Sci. 2020, 10, 2310. [CrossRef]

7. Yang, H.; Cao, J.; Hou, X. Characteristics of Aeolian Dune, Wind Regime and Sand Transport in Hobq Desert, China. Appl. Sci. 2019, 9, 5543. [CrossRef]

8. Wang, W.; Dun, H.; He, W.; Huang, N. Wind Tunnel Measurements of Surface Shear Stress on an Isolated Dune Downwind a Bridge. Appl. Sci. 2020, 10, 4022. [CrossRef] 
9. Raveh-Amit, H.; Tsesarsky, M. Biostimulation in Desert Soils for Microbial-Induced Calcite Precipitation. Appl. Sci. 2020, 10, 2905. [CrossRef]

10. Cheng, W.-C.; Xue, Z.-F.; Wang, L.; Xu, J. Using Post-Harvest Waste to Improve Shearing Behaviour of Loess and Its Validation by Multiscale Direct Shear Tests. Appl. Sci. 2019, 9, 5206. [CrossRef]

11. Katra, I. Comparison of Diverse Dust Control Products in Wind-Induced Dust Emission from Unpaved Roads. Appl. Sci. 2019, 9, 5204. [CrossRef]

12. Hanegbi, N.; Katra, I. A Clay-Based Geopolymer in Loess Soil Stabilization. Appl. Sci. 2020, 10, 2608. [CrossRef]

Publisher's Note: MDPI stays neutral with regard to jurisdictional claims in published maps and institutional affiliations.

(C) 2020 by the author. Licensee MDPI, Basel, Switzerland. This article is an open access article distributed under the terms and conditions of the Creative Commons Attribution (CC BY) license (http://creativecommons.org/licenses/by/4.0/). 